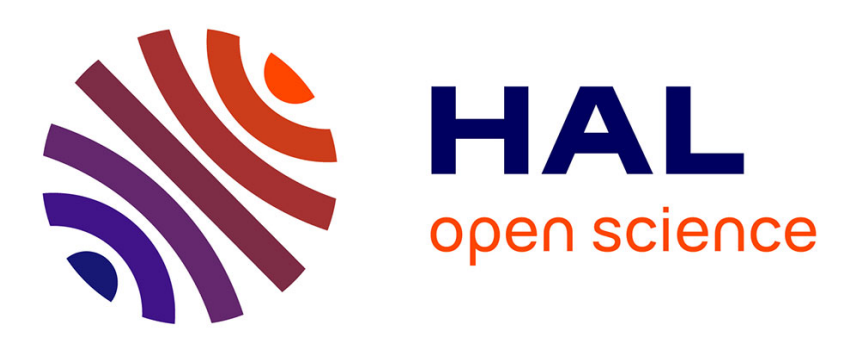

\title{
The effect of forest fragments on abundance, diversity and species composition of predatory ants in sugarcane fields
}

\author{
Luan A. O. Santos, Armin Bischoff, Odair Aparecido Fernandes
}

\section{To cite this version:}

Luan A. O. Santos, Armin Bischoff, Odair Aparecido Fernandes. The effect of forest fragments on abundance, diversity and species composition of predatory ants in sugarcane fields. Basic and Applied Ecology, 2018, 33, pp.58-65. 10.1016/j.baae.2018.08.009 . hal-01930443

HAL Id: hal-01930443

https://hal-univ-avignon.archives-ouvertes.fr/hal-01930443

Submitted on 3 Dec 2018

HAL is a multi-disciplinary open access archive for the deposit and dissemination of scientific research documents, whether they are published or not. The documents may come from teaching and research institutions in France or abroad, or from public or private research centers.
L'archive ouverte pluridisciplinaire HAL, est destinée au dépôt et à la diffusion de documents scientifiques de niveau recherche, publiés ou non, émanant des établissements d'enseignement et de recherche français ou étrangers, des laboratoires publics ou privés. 


\title{
The effect of forest fragments on abundance, diversity and species composition of predatory ants in sugarcane fields
}

\author{
Luan A.O. Santos ${ }^{\mathrm{a}, *}$, Armin Bischoff ${ }^{\mathrm{b}}$, Odair A. Fernandes ${ }^{\mathrm{c}}$ \\ ${ }^{a}$ Faculdades Associadas de Uberaba, Avenida do Tutunas 720, Vila Celeste, Uberaba, Minas Gerais 38061-500, \\ Brazil \\ ${ }^{\mathrm{b}}$ Mediterranean Institute of Biodiversity and Ecology - IMBE (Univ Aix-Marseille, Univ Avignon, CNRS, IRD), \\ University of Avignon, Agroparc, BP 61207, F-84911 Avignon Cedex 9, France \\ 'São Paulo State University, Rod. Prof. Paulo Donato Castellane km 5, Jaboticabal, SP 14884-000, Brazil
}

Received 17 December 2017; accepted 30 August 2018

\begin{abstract}
Habitat loss and fragmentation have gradually caused loss of diversity and consequently the decline of ecological services. This study aimed to evaluate the effect of tropical forest fragments as natural habitats (river valley fragments and plateau fragments) on the community of predatory and omnivorous ants in nearby sugarcane fields. Twenty fields adjacent to these fragments were selected and evaluated one (dry season) and four months (rainy season) after harvest. In each field, ants were sampled in five linear plots ( $10 \mathrm{~m}$ inside the fragment, $0 \mathrm{~m}$ (field path between field and fragment), $5 \mathrm{~m}, 50 \mathrm{~m}$ and $100 \mathrm{~m}$ inside the crop fields). Each plot comprised ten sardine baits in a row parallel to the field edge. Species richness and frequency of ant species decreased with increasing distance from the forest fragments. Inside fields, species richness and frequency were higher during the period of vegetative growth (rainy season) than after harvest (dry season). Ant communities of sugarcane fields and forest fragments were more similar later in the season than directly after sugarcane harvest suggesting recolonization of the fields from the fragments. Several ant species were limited to forest fragments after harvest but occurred later in the season also in sugarcane fields confirming the potential contribution of fragments to the recolonization process and therefore to biological control of sugarcane-dominated pest insects.
\end{abstract}

Keywords: Predatory ants; Biodiversity; Biological control; Habitat fragmentation; Atlantic rain forest

\section{Introduction}

Agricultural production has been intensified during recent decades resulting in large areas of monocultures, and consequently, in a loss of natural and semi-natural areas and in an increased use of agrochemicals (Tscharntke, Klein, Kruess,

\footnotetext{
* Corresponding author.

E-mail address: luan.odorizzi@fazu.br (L.A.O. Santos).
}

Steffan-Dewenter, \& Thies 2005; Kennedy et al. 2013). With the increase of crop fields, semi-natural habitats have also been increasingly fragmented (Tscharntke et al. 2012) causing a rapid reduction of species interactions and ecological services (Tylianakis, Didham, Bascompte, \& Wardle 2008). The resulting loss of biodiversity (Pimm \& Raven 2000) has led to a simplification and homogenization of plant and animal communities, affecting the stability of natural and agricultural ecosystems (McKinney \& Lockwood 1999). In large-scale monospecific agrosystems, Prasifka, Heinz, and 
Winemiller (2004) showed that losses in plant diversity have a negative effect on the composition and stability of arthropod populations.

Species diversity is heterogeneously distributed in different habitats, landscapes, and regions (Rosenzweig 1995). The factors that allow this heterogeneity are variable and depend on the scale of the analysis and the studied organisms (Boehning-Gaese 1997; Rahbek 2005; Fahr \& Kalko 2011). Tews et al. (2004) found that structurally complex habitats support greater species richness because they provide more ecological niches including available resources (habitat heterogeneity hypothesis). Consequently, the distribution of beneficial arthropods in agricultural landscapes has also consequences for biological control services in various agricultural crops. Morever, the movement of these beneficials between patches is a spreading-risk strategy necessary for their own survival as well as for their progeny.

In Brazil, sugarcane dominated agricultural landscapes represent such an example of large-scale intensive agriculture with few semi-natural habitats. In our study area (São Paulo state), large crop fields are only interrupted by relatively small fragments of the former Atlantic rain forest either along river valleys (gallery forests) or on slopes and plateaus. In addition, the need for larger areas and higher sugarcane production has recently led to the expansion of sugarcane to former citrus orchards and extensive pasture. Information on the contribution of these forest fragments to the biological control of insect pests in agro-ecosystems is scarce.

Ant species are important natural enemies of insect pests in sugarcane and thus contribute to biological control. In the US, the invasive fire ant Solenopsis invicta Buren (Hymenoptera: Formicidae) contributes to the regulation of the sugarcane borer, Diatraea saccharalis (Fabricius) (Lepidoptera Crambidae) (Adams, Summers, Lofgren, Focks, \& Prewitt 1981; Choate \& Drummond 2011). The ant species does not occur in our study area but Rossi \& Fowler (2000) found that generalist ants contribute to the reduction of sugarcane infestation by the sugarcane borer in the Brazilian state of São Paulo. A previous study showed that ants may consume up to $70 \%$ of $D$. saccharalis eggs in sugarcane fields, greatly reducing pest population densities (Santos, unpublished data). When evaluating the myrmecofauna in sugarcane fields of the same region, Rossi \& Fowler (2004) found that Solenopsis was the predominant ant genus. Even non-herbivorous ant species may have negative effects on crop plants if they co-occur with hemipteran pest insects providing honeydew (Choate \& Drummond 2011). However, in most cases such anthemipteran interactions are beneficial for crop plants since ants attack other more harmful pests (Styrsky \& Eubanks 2007). Ant colonies of sugarcane fields are strongly reduced by agricultural practices such as soil tillage and, consequently, re-colonization from outside the fields is required to re-establish populations after sugarcane plantation (Choate \& Drummond 2011). Semi-natural structures are known to provide resources and other habitat functions for ant species (Offenberg 2015). Thus, it can be assumed that forest frag- ments in sugarcane-dominated landscapes play an important role in such re-colonization processes.

In the present study, we analyzed spatial distribution patterns of predatory ant species along gradients from forest fragments into sugarcane fields. We hypothesized that (1) predatory ant species are more frequent close to forest fragments providing shelter and resources and that their abundance decreases with distance; (2) ant species that colonize sugarcane fields can also be found inside fragments, confirming the hypothesis of potential colonization of field from fragments; (3) ant communities differ between river valley and plateau fragments but distance effects are similar.

\section{Materials and methods}

\section{Study sites}

The study was carried out in sugarcane plantations located near forest fragments in the Jaboticabal municipality of São Paulo state in Southeastern Brazil (Fig. 1). The climate is characterized by subtropical-mesothermic, dry winter and a rainy summer season, with an annual rainfall of $1285 \mathrm{~mm}$, a mean temperature of $22^{\circ} \mathrm{C}$, and a mean relative humidity of $70.6 \%$. The study area is located in a transition zone between Atlantic rain forest (Mata Atlantica) and the drier savannah systems (Cerrado).

Ants were sampled in twenty different sugarcane fields and in adjacent forest fragments, nine of which were located on plateaus and slopes (plateau fragments) and eleven close to rivers and creeks (river valley fragments, Fig. 1). Plateau fragments are often disturbed, with a higher cover of shrub and liana species compared to river valley fragments. River valley fragments as remnants of gallery forests are under national protection (Permanent Preservation Areas, PPA) to improve water quality of catchment areas. Afforestation of gallery forests is quite common in the study area resulting in a lack of older trees. Moreover, there are also differences in abiotic factors compared with plateau fragments (soil humidity, microclimate). The distance between collection fields was at least $500 \mathrm{~m}$ and average field size was $10 \mathrm{ha}$. Sugarcane was harvested mechanically and the straw (chopped leaves and stalk tips) was left on the soil. No insecticides were applied during the study period.

\section{Design and measurements}

At each selected site, a transect was set up from inside the forest fragment to a distance of $100 \mathrm{~m}$ into the sugarcane field. Ants were sampled at five different distances along the transect. Field paths usually separating forest fragments and crop were used as the $0-\mathrm{m}$ line. Sampling inside the fragments was performed at a distance of $10 \mathrm{~m}$ from this $0-\mathrm{m}$ line. Inside the sugarcane field, ants were sampled at distances of $5 \mathrm{~m}, 50 \mathrm{~m}$, and $100 \mathrm{~m}$. Sampling was carried out using bait traps that 


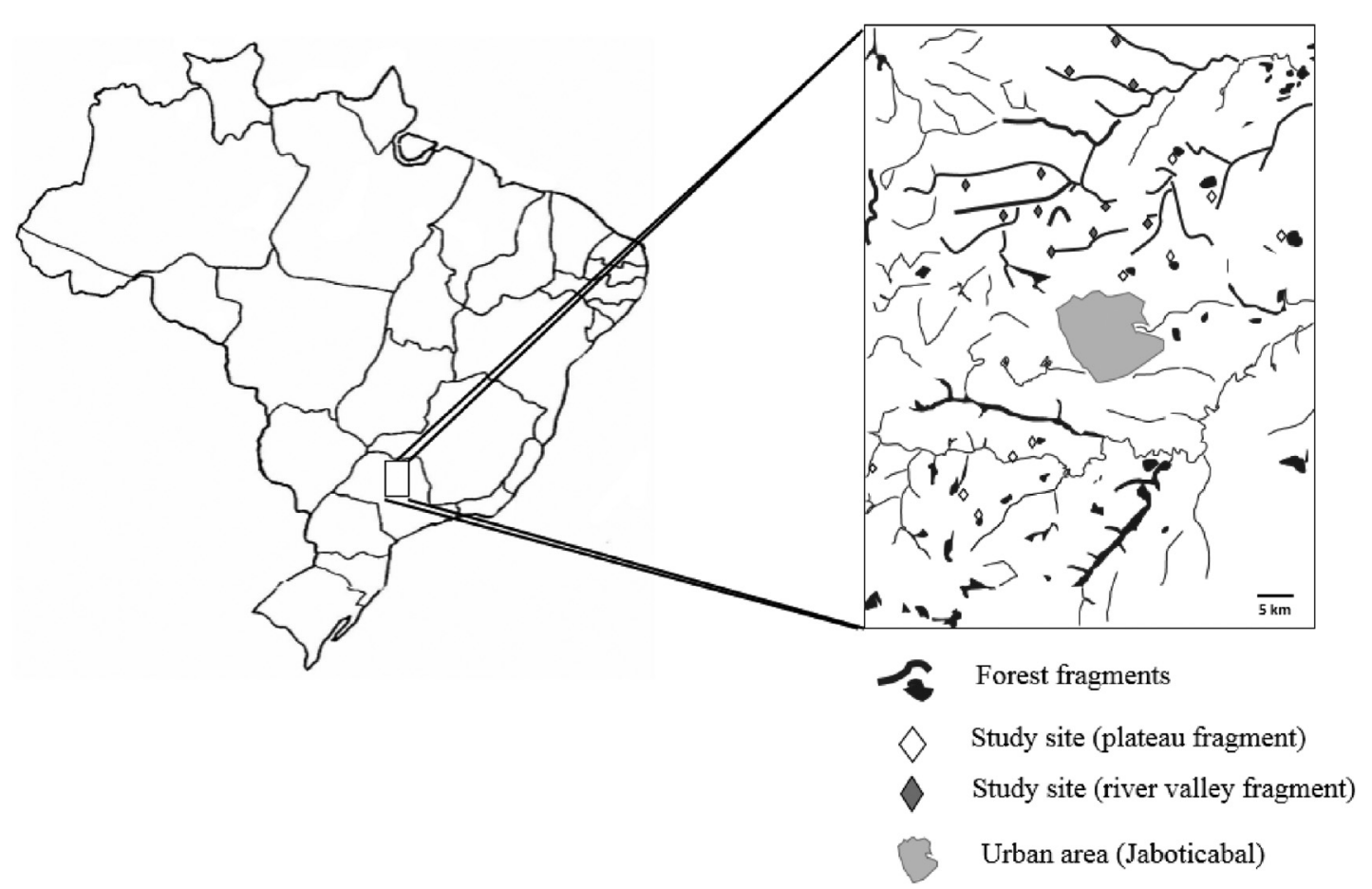

Fig. 1. Position of study sites (transects) and forest fragments in a sugarcane-dominated agricultural landscape in Brazil.

specifically attract carnivorous and omnivorous but not herbivorous ants (Fonseca \& Diehl 2004). As a bait trap we used five grams of canned sardines that were exposed on paper napkin $(20 \times 20 \mathrm{~cm})$. At each distance, ten bait traps were placed every $10 \mathrm{~m}$ along a line parallel to the field edge resulting in a total of 50 traps per transect. After $30 \mathrm{~min}$ of exposure, baits and attracted ants were put into plastic bags and transferred to the lab. Ants were sorted by species and all samples were stored in $80 \%$ alcohol before final identification. Sampled ants were identified to species, although in some cases a number was given to species instead of a full name using a reference collection (Suguituru, Morini, Feitosa, \& Silva 2015). Ants were sampled twice: one month after sugarcane harvest at the end of the dry period (October 2014), and four months later during the rainy season corresponding to the middle of the growing season (January 2015).

\section{Statistical analysis}

Linear models including distance as continuous factor and fragment type as a categorical factor were tested. Both factors were considered as fixed. A repeated measures design was applied using date as repeated measures factor and including all factor $\times$ date interactions. Normality and homoscedasticity were tested before analysis. Analyses were performed using PROC MIXED (SAS Institute, Cary, NC, USA). In the case of significant interactions between distance and the two fixed factors, separate regressions were calculated for date and fragment type to analyze the relationship between distance and ant diversity or abundance. We fitted the number of ant species at each distance (over ten bait traps) and the number of traps per distance occupied by each ant species (ant frequency) as response variables. Frequency values used as abundance estimates can reach a maximum value of ten if a species was found in all bait traps at a given distance. In order to analyze biodiversity changes along transects, $\beta$ diversity was calculated as the difference between $\gamma$ diversity and mean $\alpha$ diversity at each transect site. $\beta$ diversity was adjusted for $\gamma$ diversity to account for different $\gamma$ diversity levels in the dry and rainy season (Anderson et al. 2011). Again, a repeated measures model was fitted to compare fragment type effects at the two sampling dates and to evaluate the fragment type $\times$ date interaction.

Multivariate statistics was used to compare predatory ant communities along transects and between sampling dates in more detail. The models were run in Canoco 5 (Smilauer $\&$ Leps 2014). Following Canoco 5 adviser, we used unimodal DCA instead of linear methods since gradient length was higher than four standard deviations. Due to the leftskewed distribution, data were $\log (\mathrm{x}+1)$ transformed prior to analysis. No down-weighting was applied but only the ten species of ants with the highest weight were included in the biplots. Because differences between forest types were small, samples from gallery and plateau forest fragments were not separated in biplots.

\section{Results}

In total, 40 ant species belonging to 14 genera were collected (Appendix Table S1 in Supplementary material). The 
Table 1. Results of mixed model ANOVA on ant species richness, frequency (total and dominant species) and relative $\beta$ diversity adjusted for $\gamma$ diversity.

\begin{tabular}{|c|c|c|c|c|c|c|c|c|c|c|c|}
\hline \multirow[t]{2}{*}{ Effect } & \multirow[t]{2}{*}{ DF } & \multicolumn{2}{|c|}{ Total richness } & \multicolumn{2}{|c|}{ Total frequency } & \multicolumn{2}{|c|}{ Relative $\beta$ diversity } & \multicolumn{2}{|c|}{ Dorymyrmex brunneus } & \multicolumn{2}{|c|}{ Pheidole oxyops } \\
\hline & & $\mathrm{F}$ & $\mathrm{P}$ & $\mathrm{F}$ & $\mathrm{P}$ & $\mathrm{F}$ & $\mathrm{P}$ & $\mathrm{F}$ & $\mathrm{P}$ & $\mathrm{F}$ & $\mathrm{P}$ \\
\hline Fragment type & 1 & 6.19 & 0.0229 & 0.14 & 0.7098 & 0.12 & 0.7358 & 0.46 & 0.5080 & 0.97 & 0.3382 \\
\hline Distance & 4 & 3.09 & 0.0174 & 2.02 & 0.0935 & - & - & 4.32 & 0.0024 & 4.94 & 0.0009 \\
\hline Distance $\times$ fragment & 4 & 0.47 & 0.7574 & 0.52 & 0.7232 & - & - & 1.02 & 0.4006 & 1.44 & 0.2239 \\
\hline Date & 1 & 16.63 & $<0.0001$ & 11.06 & 0.0011 & 0.16 & 0.6880 & 22.74 & $<0.0001$ & 0.10 & 0.7517 \\
\hline Date $\times$ fragment & 1 & 0.23 & 0.6345 & 0.69 & 0.4081 & 1.23 & 0.2740 & 1.41 & 0.2367 & 0.16 & 0.6878 \\
\hline Distance $\times$ date & 4 & 1.07 & 0.3737 & 1.25 & 0.2900 & - & - & 1.60 & 0.1763 & 0.91 & 0.4597 \\
\hline Distance $\times$ date $\times$ fragment & 4 & 2.49 & 0.0450 & 125 & 0.2936 & - & - & 1.09 & 0.3634 & 0.37 & 0.8317 \\
\hline
\end{tabular}

samples taken in October 2014 (dry season, one month after harvest) contained 25 species of ants whereas those taken in January 2015 (rainy season, four months after harvest) contained 33 species. Eighteen species were found at both dates, seven and 15 species were specific to the October and January sampling dates, respectively. The most diverse genera was Pheidole, with 18 species ( $45.0 \%$ of the total), followed by Camponotus with six species (15\%). Five species were common to all sites: Crematogaster quadriformis Roger, 1983, Dorymyrmex brunneus Forel, 1908, Pheidole oxyops Forel, 1908, Pheidole radoskowskii Mayr, 1884 and Pseudomyrmex termitarius Smith, 1855 (Appendix Table S1 in Supplementary material). After harvest, we found seven species only in forest fragments and three species only in sugarcane fields whereas fifteen species were common to both habitats. Three months later, three species were exclusive to the fragment areas and eight species were exclusive to sugarcane whereas 21 species occurred in both habitats.

The species richness of ants was negatively related to the distance from the forest fragments (Table 1, Fig. 2). However, the significant distance $\times$ fragment type $\times$ date interaction indicated that the distance effect depended on season and fragment type. The distance effect was stronger after the harvest (dry season) than three months later (rainy season) and this was more evident at plateau than at river valley sites. However, the species richness-distance relationship showed a unimodal pattern at the first sampling date in river valleys. Species richness was generally higher close to river valley fragments than close to plateau fragments. The harvest date main effect was significant with lower species richness after sugarcane harvest. The mean $\beta$ diversity indicating ant community differentiation along transects was not different between fragment types and dates when adjusted for differences in $\gamma$ diversity (Table 1 ). The mean $\gamma$ diversity significantly increased from the first to the second sampling date $\left(\mathrm{F}_{1,36}=8.38, \mathrm{P}=0.0064\right)$.

The frequency of ants decreased with distance from forest fragments but the distance effect was only significant at $\mathrm{P}=0.09$ (Table 1, Fig. 3). Interactions with time and fragment type were not significant indicating that distance effects on frequency are more stable than those on species richness. Again, the date effect was significant with a much higher fre- quency four months after harvest whereas fragment types did not influence overall ant frequency.

Do. brunneus and Ph. oxyops were the most abundant species. The distance effect was significant in both species and could be explained by a decrease in frequency with distance from forest fragments (Table 1). The interactions with sampling date and fragment type were not significant confirming the consistent effect of distance on the dominant species. A higher frequency of Do. brunneus was observed at the second sampling date (rainy season), whereas differences between dates were not significant for Ph. oxyops.

The DCA biplots showed a large overlap of ant communities in forest fragment and sugarcane fields (Fig. 4). However, one month after harvest (Fig. 4A), ant communities were more separated between forest fragments and sugarcane fields than four months after harvest (Fig. 4B). At the first date, forest fragment samples were concentrated in the upper right part and sugarcane samples in the lower left part of the biplots. At the second date, this partial separation disappeared, suggesting a movement of ant species that were related to one of the habitats at the first date. Pheidole radeskowskii Mayr, 1884 and Camponotus crassus Mayr, 1862 occurred at the first date together with forest fragments sites in the upper right part suggesting a preference for this habitat. Both species occurred within sugarcane site polygons at the second sampling date suggesting a colonization from forest fragments into sugarcane fields. In general, the variation between communities largely decreased from the post-harvest to the growing season date.

\section{Discussion}

We found a reduction in ant species richness and frequency with increasing distance from forest fragments. Forest fragments comprise a higher variety of plant species providing floral and extra-floral nectar, litter, and branches, which strongly affects the diversity of ant communities. Thus, the greater variability in spatial structure, food and nesting resources may have led to a higher amount of ant species in these habitats (Mezger \& Pfeiffer 2011; Saad, SouzaCampana, Bueno, \& Morini 2017). Vegetation structure of 


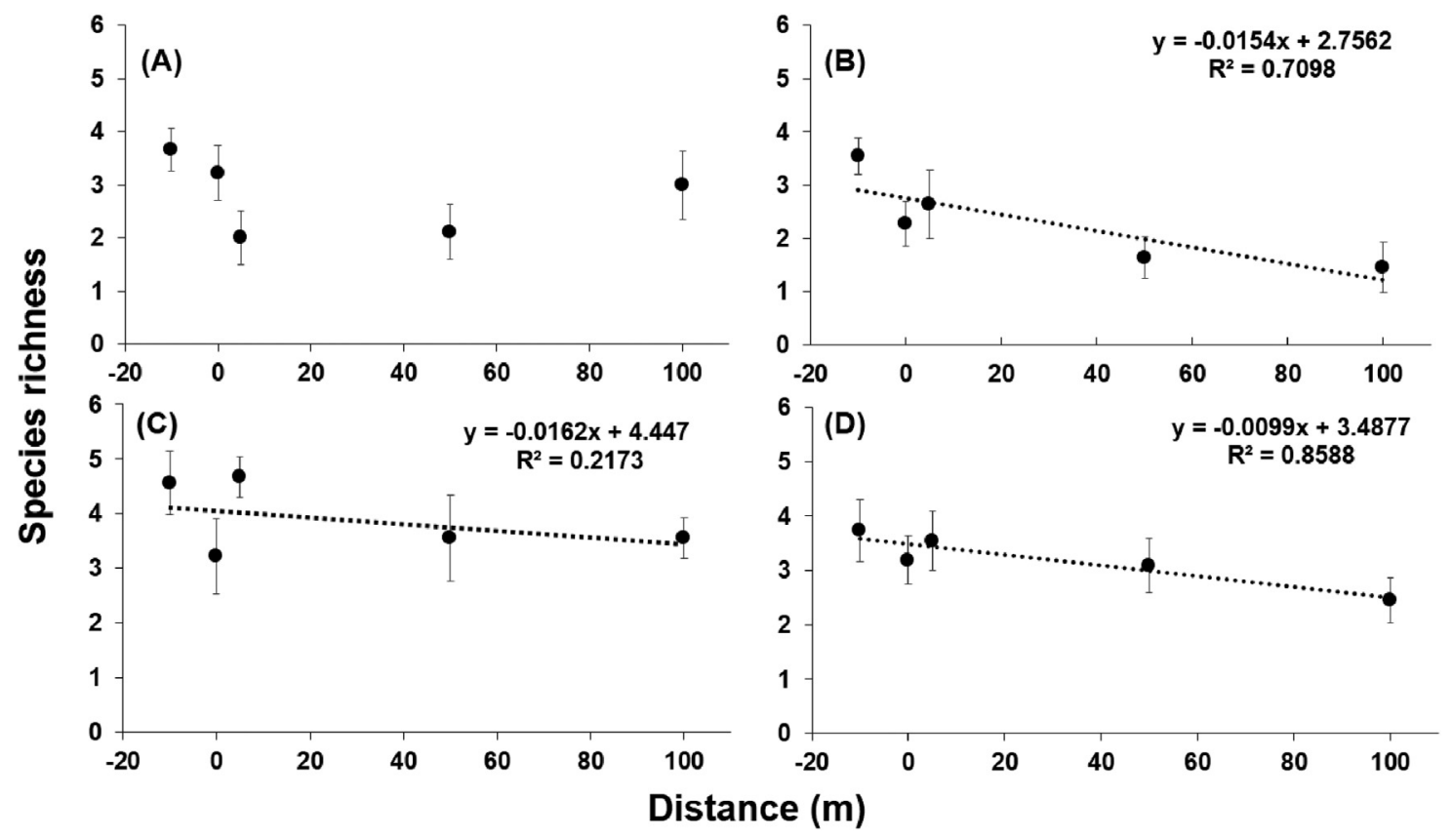

Fig. 2. Ant species richness along transects from inside forest fragments (left) into sugarcane fields (right) for two different sampling dates and fragment types: (A): one month after harvest, river valley; (B): one month after harvest, plateau; (C): four months after harvest, river valley; (D): four months after harvest, plateau. Regression lines are provided for significant relationships. Mean values \pm SE.

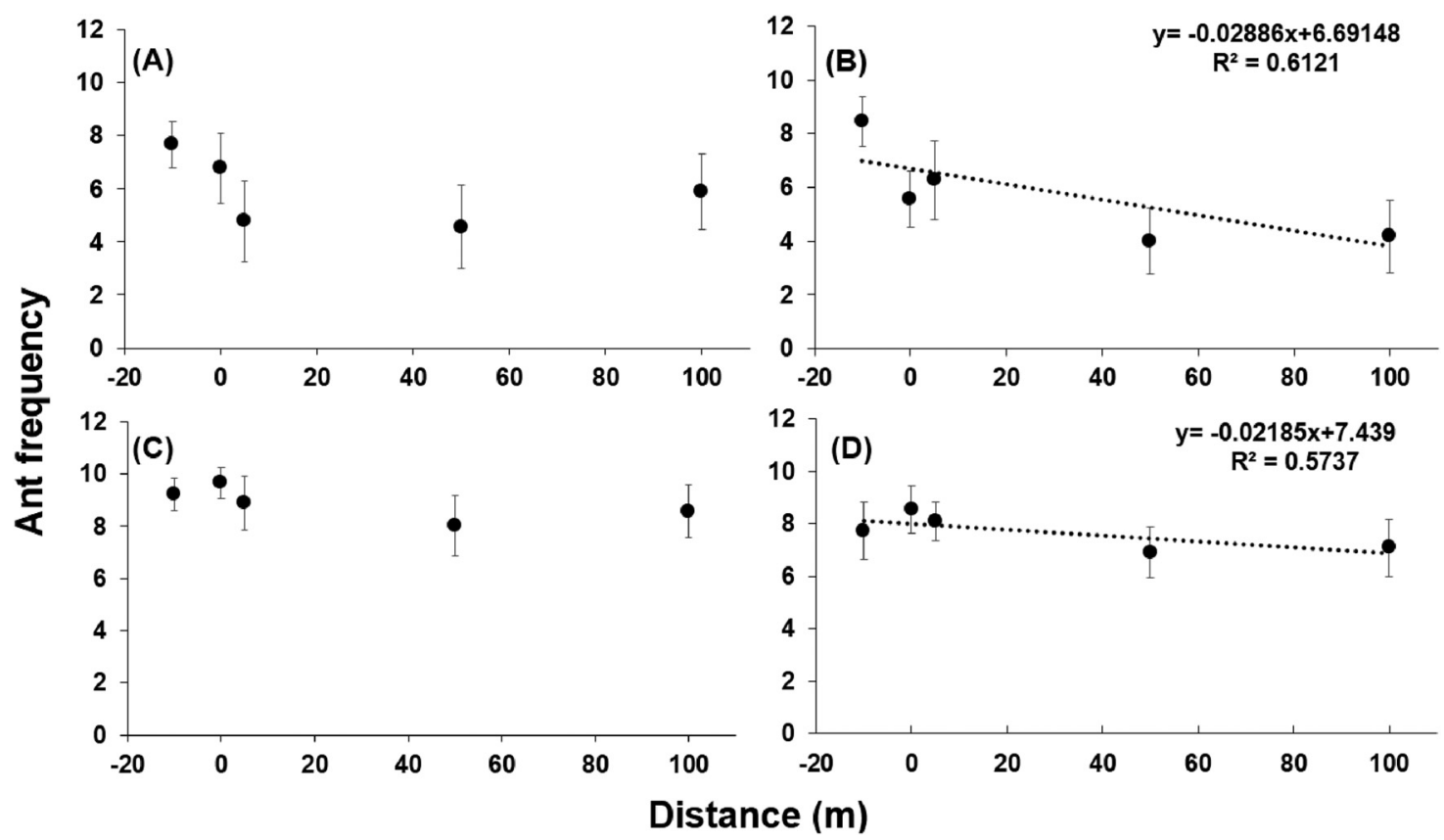

Fig. 3. Ant frequency along transects from inside forest fragments (left) into sugarcane fields (right) for two different sampling dates and fragment types. Ant frequency is the number of occupied bait traps per distance averaged over all species and all sites within date and fragment type. (A) One month after harvest, river valley; (B) one month after harvest, plateau; (C) four months after harvest, river valley; (D) four months after harvest, plateau. Regression lines are provided for significant relationships. Mean values $\pm \mathrm{SE}$.

agroecosystems is less diverse, not allowing a high diversity of ant species (Offenberg 2015). In addition, the presence of trees may provide greater soil coverage, protection against high temperatures and lower humidity variation favoring ant species (Gomes, Iannuzzi, \& Leal 2010). These habitat features may influence dominance structure of ant communities and allow the existence of higher ant species numbers in forest fragments (Perfecto \& Vandermeer 1994, 1996). Our data 


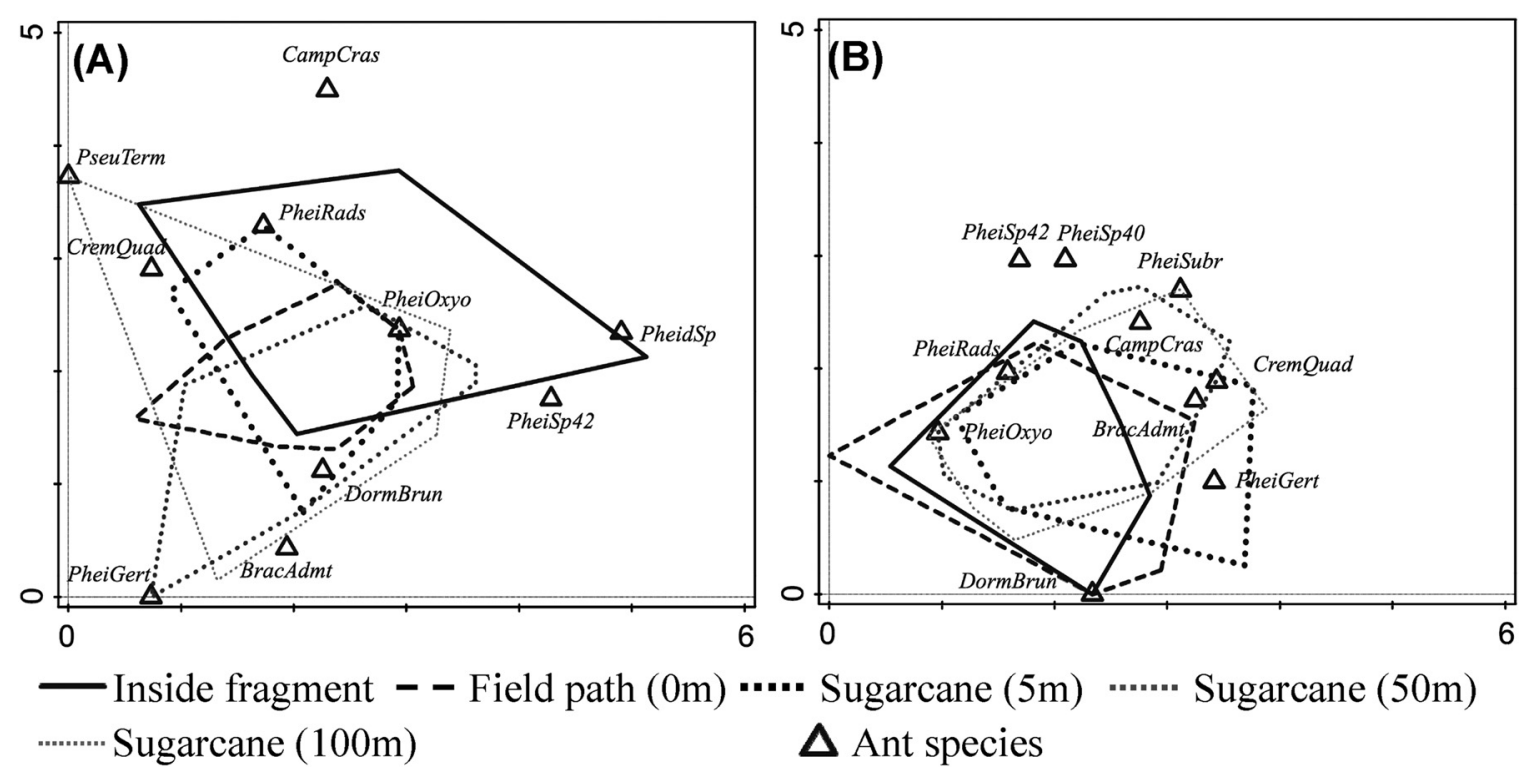

Fig. 4. Detrended correspondence analysis (DCA) on predatory ant communities one month (A, dry season) and four months (B, rainy season) after sugarcane harvest. Polygons indicate the position of the outmost samples within distance classes: forest fragments, field paths between fragment and sugarcane fields (three distances). The first two axes explained $29 \%$ of total variation in (A) and 22\% in (B).

confirm the results of several other studies showing that forest fragments are important to maintain ant and other arthropod diversity in agricultural landscapes (Lucey et al. 2014; Gray, Simmons, Fayle, Mann, \& Slade 2016) although spill-over effects from fragments into fields were not always very strong (Lucey \& Hill, 2012; Gray \& Lewis 2014; Gray et al. 2016).

The species Cr. quadriformis, Do. brunneus, Ph. oxyops, Ph. radoskowski, and Pseudomyrmex termitarius (Smith, 1855) were frequent in forest fragments and sugarcane fields. Pheidole oxyops was a dominant species in both habitats whereas Do. brunneus was particularly dominant in sugarcane fields. Agroecosystems are intensively managed without decomposing trunks or trees, limiting potential nesting sites and therefore ant diversity (Armbrecht, Perfecto, \& Vandermeer 2004). In addition, the high competitiveness of these two ant species may further limit ant species richness in crops (Holldobler \& Wilson 1990; Andersen 2000). Dorymyrmex species are very competitive in disturbed (Hölldobler \& Wilson 1990; Andersen 1997; Majer \& Nichols 1998) and open (Cuezzo \& Guerrero 2012) habitats, which explains their high abundance in crop fields compared with forest remnants. Do. brunneus is abundant in sugarcane fields (Souza et al. 2010) and is an important predator of the sugarcane borer $D$. saccharalis.

The relatively high overlap of ant species captured in forest fragments and in sugarcane fields indicated that these natural habitats are potential refuges of ant species regulating pest insects in sugarcane fields during unfavorable environmental periods such as harvest or soil tillage. Differences between fragments and sugarcane fields were larger in October after disturbance by sugarcane harvest than later in the growing season. This difference did not result in significant changes in $\beta$ diversity between these two sampling dates, showing that community shifts based on presence/absence of species were not very strong. However, multivariate analyses taking into account ant frequencies separated ant communities of sugarcane fields after disturbance by sugarcane harvest whereas three months later this separation disappeared. In the postharvest period, the number of ant species occurring in both habitats was lower than later in the season. Three months later most species limited to forest fragments in the first survey were also found in sugarcane fields. Litter cover increasing with crop growth may have favored re-colonization by ant species (Silva, Bieber, Corrêa, \& Leal 2011). The contribution of forest fragments to diversity and abundance of arthropods in adjacent crop fields and to related ecosystem services have been demonstrated in several studies (Klein et al. 2006; Gray \& Lewis 2012; Lucey \& Hill 2012) including ant communities (Lucey et al. 2014). However, effects on functionally important groups were not always apparent. Gray et al. (2016) found a limited role of such natural habitats as sources of ants and dung beetles in tropical oil palm plantations, and Lucey and Hill (2012) failed to show spillover effects from fragments into such plantations for ants.

Plateau fragments showed a lower richness of ant species when compared to river valley fragments. The latter fragment type may have provided more resources for ant species, such as shelter and food availability (Tews et al. 2004; Stein, Gerstner, \& Kreft 2014). River valley fragments keep a relatively high humidity even during the dry season with increases productivity whereas drought limits plant growth and thus resource availability in plateau fragments. Species composition of plateau fragments was a subset of river valley fragments confirming that a limited number of ecological niches was available in plateau fragments. 
Our study demonstrated that remnant forest fragments are important habitats of predatory and omnivorous ant species that are involved in the regulation of sugarcane crop herbivores (Choate \& Drummond 2011; Lucey et al. 2014; Offenberg 2015). The similarity in species composition between these natural habitats and sugarcane fields confirmed the potential refuge function of forest fragments. Although not visible in $\beta$ diversity comparisons between sampling dates, multivariate analysis based on ant frequencies confirmed a colonization of crop fields from forest fragments, since habitat differences in community composition after harvest disappeared later on in in the growing season. These findings were similar in sugarcane fields close to river valley and plateau fragments as the major forest remnants of the study region.

\section{Acknowledgements}

The authors are grateful to Debora Rodrigues de Souza Campana and Otávio Guilherme Morais da Silva, UMC, Mogi das Cruzes, Brazil, who kindly identified the ants. Scholarship was provided to the first author by CAPES (Coordenação de Aperfeiçoamento de Pessoal de Nível Superior).

\section{Appendix A. Supplementary data}

Supplementary data associated with this article can be found, in the online version, at https://doi.org/ 10.1016/j.baae.2018.08.009.

\section{References}

Adams, C. T., Summers, T. E., Lofgren, C. S., Focks, D. A., \& Prewitt, J. C. (1981). Interrelationship of ants and the sugarcane borer in Florida sugarcane fields. Environmental Entomology, $10,415-418$.

Andersen, A. N. (1997). Functional groups and patterns of organization in North American ant communities: A comparison with Australia. Journal of Biogeography, 24, 433-460.

Andersen, A. N. (2000). A global ecology of rain forest ants: Functional groups in relation to stress and disturbance. In D. Agosti, J. D. Majer, L. Alonso, \& T. Shultz (Eds.), Ants: Standard methods for measuring and monitoring biodiversity (pp. 25-34). Washington DC: Smithsonian Institution Press.

Anderson, M. J., Crist, T. O., Chase, J. M., Vellend, M., Inouye, B. D., Freestone, A. L., et al. (2011). Navigating the multiple meanings of $\beta$ diversity: A roadmap for the practicing ecologist. Ecology Letters, 14(1), 19-28.

Armbrecht, I., Perfecto, I., \& Vandermeer, J. (2004). Enigmatic biodiversity correlations: Ant diversity responds to diverse resources. Science, 304, 284-286.

Boehning-Gaese, K. (1997). Determinants of avian species richness at different spatial scales. Journal of Biogeography, 24, 49-60.
Choate, B., \& Drummond, F. A. (2011). Ants as biological control agents in agricultural cropping systems. Terrestrial Arthropod Reviews, 4, 157-180.

Cuezzo, F., \& Guerrero, R. J. (2012). The ant genus Dorymyrmex Mayr (Hymenoptera: Formicidae: Dolichoderinae) in Colombia. Psyche, 1-24.

Fahr, J., \& Kalko, E. K. V. (2011). Biome transitions as centres of diversity: Habitat heterogeneity and diversity patterns of West African bat assemblages across spatial scales. Ecography, 34, $177-195$.

Fonseca, R. C., \& Diehl, E. (2004). Riqueza de formigas (Hymenoptera, Formicidae) epigéicas em povoamentos de Eucalyptus spp. (Myrtaceae) de diferentes idades no Rio Grande do Sul, Brasil. Revista Brasileira de Entomologia, 48, 95-100.

Gomes, J. P., Iannuzzi, L., \& Leal, I. R. (2010). Resposta da comunidade de formigas aos atributos dos fragmentos e da vegetação em uma paisagem da Floresta Atlântica Nordestina. Neotropical Entomology, 39, 898-905.

Gray, C., Simmons, B., Fayle, T., Mann, D. J., \& Slade, E. M. (2016). Are riparian forest reserves sources of invertebrate biodiversity spillover and associated ecosystem functions in oil palm landscapes? Biological Conservation, 194, 176-183.

Gray, C. L., \& Lewis, O. T. (2014). Do riparian forest fragments provide ecosystem services or disservices in surrounding oil palm plantations? Basic and Applied Ecology, 15, 693-700.

Hölldobler, B., \& Wilson, E. O. (1990). The ants. Cambridge: Harvard University Press.

Kennedy, C. M., Lonsdorf, E., Neel, M. C., Williams, N. M., Ricketts, T. H., Winfree, R., et al. (2013). A global quantitative synthesis of local and landscape effects on wild bee pollinators in agroecosystems. Ecology Letters, 16, 584-599.

Lucey, J. M., \& Hill, J. K. (2012). Spillover of insects from rain forest into adjacent oil palm plantations. Biotropica, 44, 368-377.

Lucey, J. M., Tawatao, N., Senior, M. J. M., Chey, V. K., Benedick, S., Hamer, K. C., et al. (2014). Tropical forest fragments contribute to species richness in adjacent oil palm plantations. Biological Conservation, 169, 268-276.

Majer, J. D., \& Nichols, O. G. (1998). Long-term recolonization patterns of ants in Western Australian rehabilitated bauxite mines with reference to their use as indicators of restoration success. Journal Applied Ecology, 35, 161-182.

McKinney, M. L., \& Lockwood, J. L. (1999). Biotic homogenization: A few winners replacing many losers in the next mass extinction. Trends in Ecology and Evolution, 14, 450-453.

Mezger, D., \& Pfeiffer, M. (2011). Partitioning the impact of abiotic factors and spatial patterns on species richness and community structure of ground ant assemblages in four Bornean Rainforests. Ecography, 34, 39-48.

Offenberg, J. (2015). Review: Ants as tools in sustainable agriculture. Journal Applied Ecology, 52, 1197-1205.

Perfecto, I., \& Vandermeer, J. (1994). Understanding biodiversity loss in agroecosystems: Reduction of ant diversity resulting from transformation of the coffee ecosystem in Costa Rica. Entomology, 2, 7-13.

Perfecto, I., \& Vandermeer, J. (1996). Microclimatic changes and the indirect loss of ant diversity in a tropical agroecosystem. Oecologia, 108, 577-582.

Pimm, S. L., \& Raven, P. (2000). Biodiversity: Extinction by numbers. Nature, 403, 843-845.

Prasifka, J. R., Heinz, K. M., \& Winemiller, K. O. (2004). Crop colonization, feeding, and reproduction by the predatory beetle, 
Hippodamia convergens, as indicated by stable carbon isotope analysis. Ecological Entomology, 29, 226-233.

Rahbek, C. (2005). The role of spatial scale and the perception of large-scale species-richness patterns. Ecology Letters, 8, 224-239.

Rosenzweig, M. L. (1995). Species diversity in space and time. Cambridge: Cambridge University Press.

Rossi, M. N., \& Fowler, H. G. (2000). Ant predation of larval Diatraea saccharalis Fab. (Lep., Crambidae) in new sugarcane in Brazil. Journal of Applied Entomology, 124, 245-247.

Rossi, M. N., \& Fowler, H. G. (2004). Predaceous ant fauna in new sugarcane fields in the state of São Paulo, Brazil. Brazilian Archives of Biology and Technology, 47, 805-811.

Saad, L. P., Souza-Campana, D. R., Bueno, O. C., \& Morini, M. S. C. (2017). Vinasse and its influence on ant (Hymenoptera: Formicidae) communities in sugarcane crops. Journal of Insect Science, 17, 11 .

Silva, P. S. D., Bieber, A. G. D., Corrêa, M. M., \& Leal, I. R. (2011). Do leaf-litter attributes affect the richness of leaf-litter ants. Neotropical Entomology, 40, 542-547.

Smilauer, P., \& Leps, J. (2014). Multivariate analysis of ecological data using CANOCO 5 (2th ed.). Cambridge University Press., $362 \mathrm{p}$

Souza, D. R., Stingel, E., Almeida, L. C. D., Munhae, C. B., MayhéNunes, A. J., Bueno, O. C., et al. (2010). Ant diversity in a sugarcane culture without the use of straw burning in south- east, São Paulo, Brazil. American Journal of Agriculture and Biological Science, 5, 183-188.

Stein, A., Gerstner, K., \& Kreft, H. (2014). Environmental heterogeneity as a universal driver of species richness across taxa, biomes and spatial scales. Ecology Letters, 17(7), 866-880.

Styrsky, J. D., \& Eubanks, M. D. (2007). Ecological consequences of interactions between ants and honeydew-producing insects. Proceedings of the Royal Society of London B: Biological Sciences, 274(1607), 151-164.

Suguituru, S. S., Morini, M. S. C., Feitosa, R. M., \& Silva, R. R. (2015). . Formigas do Alto Tietê (Vol. 6) Bauru: Canal., 456 p.

Tews, J., Brose, U., Grimm, V., Tielbörger, K., Wichmann, M. C., Schwager, M., et al. (2004). Animal species diversity driven by habitat heterogeneity/diversity: The importance of keystone structures. Journal of Biogeography, 31(1), 79-92.

Tscharntke, T., Klein, A. M., Kruess, A., Steffan-Dewenter, I., \& Thies, C. (2005). Landscape perspectives on agricultural intensification and biodiversity-Ecosystem service management. Ecology Letters, 8, 857-874.

Tscharntke, T., Tylianakis, J. M., Rand, T. A., Didham, R. K., Fahrig, L., Batáry, P., et al. (2012). Landscape moderation of biodiversity patterns and processes-Eight hypotheses. Biological Review, 87, 661-685.

Tylianakis, J. M., Didham, R. K., Bascompte, J., \& Wardle, D. A. (2008). Global change and species interactions in terrestrial ecosystems. Ecology Letters, 11, 1351-1363. 